\title{
Novel Indole Derivatives as Potential Imaging Agents for Alzheimer's Disease
}

\author{
Lihai Yu, ${ }^{\dagger \neq}, *$ Matthias Scheunemann, ${ }^{\dagger}$ Winnie Deuther-Conrad, ${ }^{\dagger}$ Achim Hiller, ${ }^{\dagger}$ Steffen Fischer, ${ }^{\dagger}$ Dietlind Sorger, ${ }^{\S}$ \\ Osama Sabri, ${ }^{\S}$ Hongmei Jia, ${ }^{\ddagger}$ Jörg Steinbach, ${ }^{\dagger}$ Peter Brust, ${ }^{\dagger}$ and Boli Liu ${ }^{\ddagger}$ \\ †Institute of Interdisciplinary Isotope Research, Leipzig, 04318, Germany. *E-mail: yu@iif-leipzig.de \\ ${ }^{\ddagger}$ Key Laboratory of Radiopharmaceuticals, (Beijing Normal University), Ministry of Education, College of Chemistry, \\ Beijing Normal University, Beijing 100875, P. R. China \\ ${ }^{\S}$ Department of Nuclear Medicine, University of Leipzig, Leipzig, 04103, Germany \\ Received August 10, 2009, Accepted October 26, 2009
}

Key Words: $\beta$-Amyloid, Indole, Positron emission tomography, Senile plaques

\begin{abstract}
Alzheimer's disease (AD), the most common form of sporadic or late-onset dementia, is characterized by progressive cognitive and functional impairment. Although the clinical tests currently performed are rather accurate, a definitive diagnosis can still only be made by examining the brain tissue after death. Postmortem diagnosis of $\mathrm{AD}$ relies in part on the accurate detection of senile plaques (SPs) and neurofibrillary tangles (NFTs), the two major defining neuropathological features of $\mathrm{AD} .{ }^{1-3}$ While NFTs consist of bundles of filaments of hyperphosphorylated microtubule-associated protein, tau, ${ }^{4}$ SPs contain mainly insoluble $A \beta_{40}$ and $A \beta_{42}$ peptides which are produced by a sequence of proteolytic cleavages from the amyloid precursor protein (APP). By targeting the cortical A $\beta$ load, in vivo imaging by SPECT or PET has the potential to support both the earlier diagnosis by assessing a histologically confirmed AD-specific target and the monitoring of the effects of amyloid lowering
\end{abstract} therapeutic approaches.

Currently, several promising amyloid PET tracers were designed and successfully synthesized to image SPs or NFTs or both in vivo and have been used in clinical trial. Based on the benzothiazole and stilbene core structures, the two PET tracer compounds $\left[{ }^{11} \mathrm{C}\right] \mathrm{PIB}{ }^{5,6}$ and $\left[{ }^{11} \mathrm{C}\right] \mathrm{SB}-13^{7,8}$ (Fig. 1) were designed and reported to image SPs in AD brain. $\left[{ }^{11} \mathrm{C}\right] \mathrm{BF}-227$ is another potential probe containing a benzoxazole core, and neuropathologic staining has demonstrated preferential binding of this agent to dense amyloid deposits in AD brain. ${ }^{9}\left[{ }^{18} \mathrm{~F}\right] \mathrm{FDDNP}^{10-12}$ (Fig. 1) was shown to accumulate in SP- and NFT-dense brain areas. Kung et al. reported on the $\left[{ }^{123} \mathrm{I}\right] \mathrm{IMPY}{ }^{13-15}$ (Fig. 1) as candidate radiotracer for imaging SPs by SPECT. The positively charged quaternary heterocyclic nitrogen of the benzothiazolium group of the $\beta$-sheet specific staining dye thioflavine $\mathrm{T}$ limits the brain entry of this potential pharmacophore while its uncharged and lipophilic derivatives $\left[{ }^{11} \mathrm{C}\right] 6-\mathrm{Me}-\mathrm{BTA}-1^{16}$ and BTA- $1^{17}$ (Fig. 2) enter the brain in amounts sufficient for imaging by PET and show some preference for SPs staining. On the contrary, the quinoline based $\left[{ }^{11} \mathrm{C}\right] \mathrm{BF}-158$ (Fig. 2) demonstrated preferred labeling of NFTs in AD brain sections by in vitro autoradiography. ${ }^{18}$

By combining the chemical structures of SP-preferring benzothiazole and NFT-preferring quinoline, we have designed and synthesized a series of fluorinated indole derivatives by removing one $\mathrm{C}$ atom from the large conjugated 6-membered

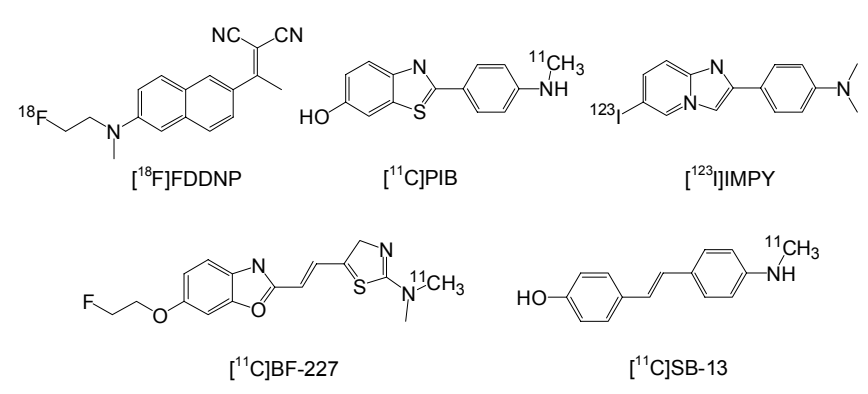

Figure 1. Structure of previously reported radiotracers for imaging amyloid plaques.
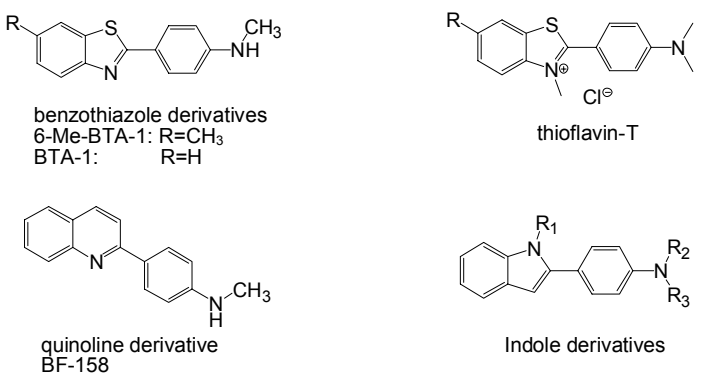

Figure 2. Structural difference/comparison between benzothiazole, quinoline and indole derivatives intended for application in plaque imaging.

quinoline ring system for radiolabelling with ${ }^{18} \mathrm{~F}$ (Fig. 2). The resulting 5-membered indole structure offers the possibility to introduce a methyl group into the $\mathrm{N}$-indole ring without parallel introduction of a positive charge into the molecule. The new compounds were investigated for their potential to displace the well described thioflavin-based $\beta$-sheet ligand $\left[{ }^{125} \mathrm{I}\right] \mathrm{IMPY}$ from its binding sites in postmortem AD brain. By this way, we expect that these compounds can be used to image SPs or NFTs or both.

\section{Experimental Section}

General. All the reagents used for chemical synthesis were commercial products without any further purification. ${ }^{1} \mathrm{H}-\mathrm{NMR}$, 
${ }^{13} \mathrm{C}-\mathrm{NMR}$, and ${ }^{19} \mathrm{~F}-\mathrm{NMR}$ spectra were obtained on the Mercury400BB "felix" spectrometer, mercury-300BB "jutta", or Gemini-200BB "Paul" with TMS as internal standard. Coupling constants are reported in Hertz. The multiplicity is defined by $\mathrm{s}$ (singlet), d (doublet), $\mathrm{t}$ (triplet), $\mathrm{b}$ (broad), and $\mathrm{m}$ (multiplet). Elementary analysis was determined by the elementar Vario EL III. Mass Spectrum was achieved by Mariwer Biospectrometry (applied biosystem, MS-TOF).

4-(1 H-Indol-2-yl)benzenamine (3a): A mixture of 1a (1.08 g, $10 \mathrm{mmol})$ and $2 \mathrm{a}(1.35 \mathrm{~g}, 10 \mathrm{mmol})$ was added to $10 \mathrm{~g}$ of PPA and stirred at $80{ }^{\circ} \mathrm{C}$ for $5 \mathrm{~h}$. After being cooled down to room temperature, the reaction mixture was poured into $200 \mathrm{~mL}$ of aqueous $\mathrm{Na}_{2} \mathrm{CO}_{3}$ solution and extracted with ethyl acetate $(3 \times$ $50 \mathrm{~mL}$ ). The organic layer was separated, washed with brine, dried with anhydrous $\mathrm{Na}_{2} \mathrm{CO}_{3}$. The mixture was purified by column chromatography (EtOAc : petroleum ether $=1: 2$ ) to get yellowish solid ( $0.9 \mathrm{~g}$; yield: $47 \%)$. The compounds $\mathbf{3 b}$ and $\mathbf{3} \mathbf{c}$ were prepared by the same method as 3a. ${ }^{1} \mathrm{H}-\mathrm{NMR}$ (400 $\left.\mathrm{MHz}, \mathrm{DMSO}-d_{6}\right) \delta 5.26(2 \mathrm{H}, \mathrm{b}), 6.55(1 \mathrm{H}, \mathrm{s}), 6.62(2 \mathrm{H}, \mathrm{d}, J=$ $8.8 \mathrm{~Hz}), 6.91(1 \mathrm{H}, \mathrm{t}, J=7.6 \mathrm{~Hz}), 6.98(1 \mathrm{H}, \mathrm{t}, J=7.6 \mathrm{~Hz}), 7.30$ $(1 \mathrm{H}, \mathrm{d}, J=7.6 \mathrm{~Hz}), 7.41(1 \mathrm{H}, \mathrm{d}, J=7.2 \mathrm{~Hz}), 7.51(2 \mathrm{H}, \mathrm{d}, J=$ $7.2 \mathrm{~Hz}), 11.15(1 \mathrm{H}, \mathrm{b}) .{ }^{13} \mathrm{C}-\mathrm{NMR}\left(100 \mathrm{MHz}, \mathrm{CDCl}_{3}\right) \delta 95.4$, $110.8,114.0,119.0,119.1,120.0,120.3,126.1,129.1,136.6$, 139.2, 148.4. EI-MS $m / z 209.12$ [M $\mathrm{M}^{+}$], (Calcd for 209.11). anal. Calcd for $\mathrm{C}_{14} \mathrm{H}_{12} \mathrm{~N}_{2}: \mathrm{C}, 80.740 ; \mathrm{H}, 5.810 ; \mathrm{N}, 13.450$. Found: C, 80.345; H, 5.860; N, 13.450 .

4-(1H-Indol-2-yl)- $\mathrm{N}$-methylbenzenamine (3b): (70\% yield, yellowish solid) ${ }^{\mathrm{l}} \mathrm{H}-\mathrm{NMR}\left(400 \mathrm{MHz}, \mathrm{CDCl}_{3}\right) \delta 2.89(3 \mathrm{H}, \mathrm{s})$, $3.87(1 \mathrm{H}, \mathrm{b}), 6.66(1 \mathrm{H}, \mathrm{s}), 6.62(2 \mathrm{H}, \mathrm{d}, J=8.8 \mathrm{~Hz}), 7.09(1 \mathrm{H}$, $\mathrm{t}, J=7.2 \mathrm{~Hz}), 7.14(1 \mathrm{H}, \mathrm{t}, J=7.6 \mathrm{~Hz}), 7.37(1 \mathrm{H}, \mathrm{d}, J=7.6 \mathrm{~Hz})$, $7.51(2 \mathrm{H}, \mathrm{d}, J=8.4 \mathrm{~Hz}), 7.59(1 \mathrm{H}, \mathrm{d}, J=7.6 \mathrm{~Hz}), 8.21(1 \mathrm{H}, \mathrm{b})$. ${ }^{13} \mathrm{C}-\mathrm{NMR}\left(100 \mathrm{MHz}, \mathrm{CDCl}_{3}\right) \delta 30.8,97.8,110.7,112.8$, $120.1,120.2,121.5,121.6,126.5,129.8,136.6,139.0,149.2$. EI-MS $m / z 223.10\left[\mathrm{M}^{+}\right]$, (Calcd for 223.12). anal. Calcd for $\mathrm{C}_{15} \mathrm{H}_{14} \mathrm{~N}_{2}: \mathrm{C}, 81.050 ; \mathrm{H}, 6.350 ; \mathrm{N}, 13.450$. Found: $\mathrm{C}, 81.11 ; \mathrm{H}$, $6.344 ; \mathrm{N}, 12.57$.

4-(1-Methyl-1H-indol-2-yl)benzenamine (3c): $(0.73 \mathrm{~g}$, yield $47 \%$, yellowish solid) ${ }^{1} \mathrm{H}-\mathrm{NMR}\left(200 \mathrm{MHz}, \mathrm{CDCl}_{3}\right) \delta 3.70$ $(3 \mathrm{H}, \mathrm{s}), 3.78(2 \mathrm{H}, \mathrm{b}), 6.45(1 \mathrm{H}, \mathrm{s}), 6.75(2 \mathrm{H}, \mathrm{d}, J=8.6 \mathrm{~Hz})$, $7.09(1 \mathrm{H}, \mathrm{t}, J=7.2 \mathrm{~Hz}), 7.20(1 \mathrm{H}, \mathrm{t}, J=7.6 \mathrm{~Hz}), 7.28(2 \mathrm{H}, \mathrm{d}$, $J=8.4 \mathrm{~Hz}), 7.32(1 \mathrm{H}, \mathrm{d}, J=8.8 \mathrm{~Hz}), 7.58(1 \mathrm{H}, \mathrm{d}, J=7.8 \mathrm{~Hz})$. ${ }^{13} \mathrm{C}-\mathrm{NMR}\left(50 \mathrm{MHz}, \mathrm{CDCl}_{3}\right) \delta 31.2,100.7,109.6,115.0,119.8$, $120.3,121.3,123.1,128.2,130.7,138.2,142.2,146.4$, EI-MS $\mathrm{m} / \mathrm{z} 223.14\left[\mathrm{M}^{+}\right]$, (calcd for 223.12). anal. Calcd for $\mathrm{C}_{15} \mathrm{H}_{14} \mathrm{~N}_{2}$ : C, 81.050; H, 6.350; N, 13.450. Found: C, 81.14; H, 6.280; N, 12.50 .

1-(4-(Methylamino)phenyl)ethanone (2b): $2 a(1 \mathrm{~g}, 7.4 \mathrm{mmol})$ was dissolved in pyridine $(3 \mathrm{~mL}) . \mathrm{Ac}_{2} \mathrm{O}(3 \mathrm{~mL})$ was added and stirred for 30 minutes at $0{ }^{\circ} \mathrm{C}$. The precipitate was filtrated, to get the product 4-acetylaminoacetophenone $1 \mathrm{~g}$; yield $77 \%$. To a solution of this acetyl derivative $(0.2 \mathrm{~g}, 1.13 \mathrm{mmol})$ in anhydrous DMF (5 mL), was added $\mathrm{NaH}(48 \mathrm{mg}, 2.0 \mathrm{mmol})$ at $0{ }^{\circ} \mathrm{C}$ within $30 \mathrm{~min}, \mathrm{CH}_{3} \mathrm{I}(0.213 \mathrm{~g}, 1.5 \mathrm{mmol})$ was dropped slowly into the reaction mixture at $0{ }^{\circ} \mathrm{C}$, keeping stirring for additional $1 \mathrm{~h}$ at room temperature. The mixture was quenched in $20 \mathrm{~mL}$ cool water, extracted with ethyl acetate and the solvent was evaporated. The residue was suspended in $\mathrm{HCl}(3 \mathrm{M})(20$ $\mathrm{mL}$ ) and refluxed for $5 \mathrm{~h}$, neutralized with $\mathrm{Na}_{2} \mathrm{CO}_{3}$, and purifi- ed with column chromatography to get the product $(2 \mathbf{b}, 0.17 \mathrm{~g}$, yield $65 \%$ ). ${ }^{1} \mathrm{H}-\mathrm{NMR}\left(300 \mathrm{MHz}, \mathrm{CDCl}_{3}\right) \delta 2.50(3 \mathrm{H}, \mathrm{s}), 2.90(3 \mathrm{H}$, s), $4.25(1 \mathrm{H}, \mathrm{b}), 6.56(2 \mathrm{H}, \mathrm{d}, J=8.7 \mathrm{~Hz}), 7.84(2 \mathrm{H}, \mathrm{d}, J=8.7 \mathrm{~Hz})$.

$\mathrm{N}$-Methyl-4-(1-methyl-1H-indol-2-yl)benzenamine (3d): Compound 3c (70 mg, $0.32 \mathrm{mmol}$ ) was dissolved in $\mathrm{MeOH}$ $(10 \mathrm{~mL})$ containing $\mathrm{NaOCH}_{3}(86 \mathrm{mg}, 1.6 \mathrm{mmol})$. Paraformaldehyde (48 $\mathrm{mg}, 1.6 \mathrm{mmol})$ was added and the reaction mixture was refluxed for 6 hours. After cooling down to $0{ }^{\circ} \mathrm{C}, \mathrm{NaBH}_{4}$ (64 mg, $1.6 \mathrm{mmol}$ ) was added in portion and the mixture was refluxed for additional $2 \mathrm{~h}$ and then diluted with the $50 \mathrm{~mL}$ of cool water, extracted with ethyl acetate $(3 \times 20 \mathrm{~mL})$. The organic layer was separated, washed with water and brine, dried $\left(\mathrm{Na}_{2} \mathrm{CO}_{3}\right)$ and purified by column chromatography (ethyl acetate : petroleum ether $=1: 4)$ to get yellowish solid $(57 \mathrm{mg}$, yield $76 \%) .{ }^{1} \mathrm{H}-\mathrm{NMR}\left(300 \mathrm{MHz}, \mathrm{CDCl}_{3}\right) \delta 2.90(1 \mathrm{H}, \mathrm{s}), 3.73$ $(3 \mathrm{H}, \mathrm{s}), 3.87(1 \mathrm{H}, \mathrm{b}), 6.47(1 \mathrm{H}, \mathrm{s}), 6.70(2 \mathrm{H}, \mathrm{d}, J=7.8 \mathrm{~Hz}), 7.12$ $(1 \mathrm{H}, \mathrm{t}, J=7.5 \mathrm{~Hz}), 7.21(1 \mathrm{H}, \mathrm{t}, J=7.5 \mathrm{~Hz}), 7.34(3 \mathrm{H}, \mathrm{d}, J=8.7$ $\mathrm{Hz}), 7.61(1 \mathrm{H}, \mathrm{d}, J=7.2 \mathrm{~Hz}){ }^{13} \mathrm{C}-\mathrm{NMR}\left(75 \mathrm{MHz}, \mathrm{CDCl}_{3}\right) \delta 30.8$, $31.2,100.5,109.5,112.3,119.8,120.2,121.2,121.6,128.3$, 130.6, 138.2, 142.5, 149.2. EI-MS m/z 237.17 [M ${ }^{+}$, (Calcd for 237.14). anal. Calcd for $\mathrm{C}_{16} \mathrm{H}_{16} \mathrm{~N}_{2}: \mathrm{C}, 81.670 ; \mathrm{H}, 6.430 ; \mathrm{N}$, 11.910. Found: C, 81.495; H, 6.785; N, 11.935 .

$\mathrm{N}$-(2-Fluoroethyl)-4-(1H-indol-2-yl)benzenamine (4a): A mixture of compound $\mathbf{3 a}(0.1 \mathrm{~g}, 0.48 \mathrm{mmol}), 1$-bromo-2-fluoroethane $(0.34 \mathrm{mg}, 2.7 \mathrm{mmol})$ and $\mathrm{Na}_{2} \mathrm{CO}_{3}(0.1 \mathrm{~g}, 0.94 \mathrm{mmol})$ in dioxane $(5 \mathrm{~mL})$ was sealed in the bottle and stirred at $110^{\circ} \mathrm{C}$ for 5 days. After being cooled to room temperature, the reaction mixture was poured into $40 \mathrm{~mL}$ of cold water, extracted with ethyl acetate, and purified by column chromatography to get the yellowish solid. $37 \mathrm{mg}$, yield $30 \%$. ${ }^{1} \mathrm{H}-\mathrm{NMR}$ ( $300 \mathrm{MHz}$, DMSO$\left.d_{6}\right) \delta 3.34(1 \mathrm{H}, \mathrm{q}, J=5.4 \mathrm{~Hz}), 3.43(1 \mathrm{H}, \mathrm{q}, J=5.4 \mathrm{~Hz}), 4.48(1 \mathrm{H}$, $\mathrm{t}, J=5.4 \mathrm{~Hz}), 4.64(1 \mathrm{H}, \mathrm{t}, J=5.4 \mathrm{~Hz}), 6.03(\mathrm{H}, \mathrm{t}, J=6 \mathrm{~Hz}), 6.58$ $(1 \mathrm{H}, \mathrm{s}), 6.68(2 \mathrm{H}, \mathrm{d}, J=8.1 \mathrm{~Hz}), 6.91(1 \mathrm{H}, \mathrm{t}), 6.98(1 \mathrm{H}, \mathrm{t}, 7.5$ $\mathrm{Hz}), 7.30(1 \mathrm{H}, \mathrm{d}, J=8.1 \mathrm{~Hz}), 7.42(1 \mathrm{H}, \mathrm{d}, J=7.5 \mathrm{~Hz}), 7.58(2 \mathrm{H}$, d, $J=8.7 \mathrm{~Hz}), 11.18(1 \mathrm{H}, \mathrm{b}) .{ }^{13} \mathrm{C}-\mathrm{NMR}\left(100 \mathrm{MHz}\right.$, DMSO- $\left.d_{6}\right)$ $\delta 42.9,43.2,81.4,83.6,95.6,110.7,112.2,119.0,119.1,120.2$, 120.3, 126.1 129.0, 136.7, 138.9, 148.1. ${ }^{19}$ F-NMR (282 MHz, DMSO- $\left.d_{6}\right) \delta$-220.7. EI-MS $m / z 255.09\left[\mathrm{M}^{+}\right]$, (Calcd for 255.13). anal. Calcd for $\mathrm{C}_{16} \mathrm{H}_{15} \mathrm{~N}_{2} \mathrm{~F}$ : C, 75.570; H, 5.950; N, 11.02. Found: C, 75.390; H, 5.911; N, 11.055 .

$\mathrm{N}$-(2-Fluoreethyl)-4-(1 $\mathrm{H}$-indol-2-yl)- $\mathrm{N}$-methylbenzenamine (4b): A mixture of compound $3 \mathrm{~b}(50 \mathrm{mg}, 0.2 \mathrm{mmol})$, 1-bromo2-fluoroethane $(0.25 \mathrm{~g}, 2 \mathrm{mmol})$ and $\mathrm{Na}_{2} \mathrm{CO}_{3}(0.11 \mathrm{~g}, 1 \mathrm{mmol})$ in $\mathrm{MeCN}(2 \mathrm{~mL})$ was sealed in a bottle and heated to $80^{\circ} \mathrm{C}$. The reaction mixture was purified according to the 4 a synthetic method to get yellowish solid (4b) $22 \mathrm{mg}$, yield $47 \%$. The compounds $\mathbf{4 c}$ and $\mathbf{4 d}$ were synthesized using $\mathbf{3 c}$ and $\mathbf{3 d}$ respectively by the same method as $\mathbf{4 b}$. The compound $4 \mathbf{e}$ was synthesized using 3d and 1-iodo-3-fluoropropane by the similiar reaction described in the preparation of $\mathbf{4 b}$. ${ }^{1} \mathrm{H}-\mathrm{NMR}(300 \mathrm{MHz}$, $\left.\mathrm{CDCl}_{3}\right) \delta 3.07(3 \mathrm{H}, \mathrm{s}), 3.66(1 \mathrm{H}, \mathrm{t}, J=5.1 \mathrm{~Hz}), 3.74(1 \mathrm{H}, \mathrm{t}, J=$ $5.1 \mathrm{~Hz}), 4.56(1 \mathrm{H}, \mathrm{t}, J=5.1 \mathrm{~Hz}), 4.71(1 \mathrm{H}, \mathrm{t}, J=5.1 \mathrm{~Hz}), 6.67$ $(1 \mathrm{H}, \mathrm{s}), 6.78(2 \mathrm{H}, \mathrm{d}, J=9.0 \mathrm{~Hz}), 7.09(1 \mathrm{H}, \mathrm{t}, J=6.9 \mathrm{~Hz}), 7.15$ $(1 \mathrm{H}, \mathrm{t}, J=7.2 \mathrm{~Hz}), 7.36(1 \mathrm{H}, \mathrm{d}, J=8.1 \mathrm{~Hz}) 7.54(2 \mathrm{H}, \mathrm{d}, J=9.0$ $\mathrm{Hz}), 7.59(1 \mathrm{H}, \mathrm{d}, J=7.5 \mathrm{~Hz}), 8.21(1 \mathrm{H}, \mathrm{b}) .{ }^{13} \mathrm{C}-\mathrm{NMR}(100 \mathrm{MHz}$, $\left.\mathrm{CDCl}_{3}\right) \delta 39.2,52.6,52.9,80.8,83.0,97.9,110.7,112.6,120.18$, $120.22,121.1,121.6,126.5,129.8,136.7,138.8,148.7$. EI-MS m/z $269.14\left[\mathrm{M}^{+}\right]$, (Calcd for 269.15). anal. Calcd for $\mathrm{C}_{17} \mathrm{H}_{17} \mathrm{~N}_{2} \mathrm{~F}$ : C, 
76.090; H, 6.390; N, 10.440. Found: C, 75.855; H, 6.420; N, 10.455.

$\mathrm{N}$-(2-Fluoroethyl)-4-(1-methyl-1 $\boldsymbol{H}$-indol-2-yl)benzenamine (4c): (yellowish solid, yield 54\%) ${ }^{1} \mathrm{H}-\mathrm{NMR}\left(400 \mathrm{MHz}, \mathrm{CDCl}_{3}\right)$ $\delta 3.49(1 \mathrm{H}, \mathrm{q}, J=5.2 \mathrm{~Hz}), 3.55(1 \mathrm{H}, \mathrm{q}, J=5.2 \mathrm{~Hz}), 3.74(3 \mathrm{H}$, s), $4.16(1 \mathrm{H}, \mathrm{b}), 4.62(1 \mathrm{H}, \mathrm{t}, J=4.8 \mathrm{~Hz}), 4.74(1 \mathrm{H}, \mathrm{t}, J=4.8$ $\mathrm{Hz}), 6.48(1 \mathrm{H}, \mathrm{s}), 6.74(2 \mathrm{H}, \mathrm{d}, J=8.8 \mathrm{~Hz}), 7.13(1 \mathrm{H}, \mathrm{t}, J=7.2$ $\mathrm{Hz}), 7.22(1 \mathrm{H}, \mathrm{t}, J=8.0 \mathrm{~Hz}), 7.35(1 \mathrm{H}, \mathrm{d}, J=8.8 \mathrm{~Hz}), 7.35(2 \mathrm{H}$, $\mathrm{d}, J=8.4 \mathrm{~Hz}), 7.61(1 \mathrm{H}, \mathrm{d}, J=7.6 \mathrm{~Hz}) .{ }^{13} \mathrm{C}-\mathrm{NMR}(100 \mathrm{MHz}$, $\left.\mathrm{CDCl}_{3}\right) \delta 31.2,44.1,44.3,81.7,83.3,100.6,109.6,113.0,119.8$, $120.2,121.3,122.5,128.2,130.7,138.2,142.1,147.4$. EI-MS $m / z 269.24\left[\mathrm{M}^{+}\right]$, (Calcd for 269.15). anal. Calcd for $\mathrm{C}_{17} \mathrm{H}_{17} \mathrm{~N}_{2} \mathrm{~F}$ : C, 76.090; H, 6.390; N, 10.440. Found: C, 75.725; H, 6.565; $\mathrm{N}, 10.120$.

$\mathrm{N}$-(2-Fluoroethyl)- $\mathrm{N}$-methyl-4-(1-methyl-1 H-indol-2-yl) benzenamine (4d): (yellowish solid, yield 69\%) ${ }^{1} \mathrm{H}-\mathrm{NMR}(400$ $\left.\mathrm{MHz} \mathrm{CDCl}_{3}\right) \delta 3.09(3 \mathrm{H}, \mathrm{s}), 3.69(1 \mathrm{H}, \mathrm{t}, J=5.2 \mathrm{~Hz}), 3.74(3 \mathrm{H}$, s), $3.75(1 \mathrm{H}, \mathrm{t}, J=5.2 \mathrm{~Hz}), 4.60(1 \mathrm{H}, \mathrm{t}, J=5.2 \mathrm{~Hz}), 4.72(1 \mathrm{H}, \mathrm{t}$, $J=5.2 \mathrm{~Hz}), 6.48(1 \mathrm{H}, \mathrm{s}), 6.81(2 \mathrm{H}, \mathrm{d}, J=8.8 \mathrm{~Hz}), 7.13(1 \mathrm{H}, \mathrm{t}$, $J=7.2 \mathrm{~Hz}), 7.22(1 \mathrm{H}, \mathrm{t}, J=7.6 \mathrm{~Hz}), 7.34(1 \mathrm{H}, \mathrm{d}, J=8.0 \mathrm{~Hz})$, $7.40(2 \mathrm{H}, \mathrm{d}, J=8.8 \mathrm{~Hz}), 7.61(1 \mathrm{H}, \mathrm{d}, J=8.0 \mathrm{~Hz}) .{ }^{13} \mathrm{C}-\mathrm{NMR}(100$ $\left.\mathrm{MHz}, \mathrm{CDCl}_{3}\right) \delta 31.2,39.2,52.6,52.9,81.1,82.8,100.5,109.6$, $112.1,119.8,120.2,121.1,121.2,130.6,128.3,138.2,142.2$, 148.6. EI-MS $m / z 283.18\left[\mathrm{M}^{+}\right]$, (Calcd for 283.16). anal. Calcd for $\mathrm{C}_{18} \mathrm{H}_{19} \mathrm{~N}_{2} \mathrm{~F}$ : C, 76.570; H, 6.780; N, 9.920. Found: C, 76.235; H, 7.051; N, 9.516 .

$\mathrm{N}$-(3-Fluoropropyl)- $\mathrm{N}$-methyl-4-(1-methyl-1 $\mathrm{H}$-indol-2-yl) benzenamine (4e): (yellowish solid, yield 38\%) ${ }^{1} \mathrm{H}-\mathrm{NMR}(300$ $\left.\mathrm{MHz} \mathrm{CDCl}_{3}\right) \delta 1.98(1 \mathrm{H}, \mathrm{m}), 2.07(1 \mathrm{H}, \mathrm{m}), 3.03(3 \mathrm{H}, \mathrm{s}), 3.57$ $(2 \mathrm{H}, \mathrm{t}, J=6.6 \mathrm{~Hz}), 3.749(3 \mathrm{H}, \mathrm{s}), 4.48(1 \mathrm{H}, \mathrm{t}, J=5.4 \mathrm{~Hz}), 4.64$ $(1 \mathrm{H}, \mathrm{t}, J=5.4 \mathrm{~Hz}), 6.48(1 \mathrm{H}, \mathrm{s}), 6.81(2 \mathrm{H}, \mathrm{d}, J=8.7 \mathrm{~Hz}), 7.13$ $(1 \mathrm{H}, \mathrm{t}, J=7.5 \mathrm{~Hz}), 7.28(1 \mathrm{H}, \mathrm{t}, J=7.5 \mathrm{~Hz}), 7.34(1 \mathrm{H}, \mathrm{d}, J=7.8$ $\mathrm{Hz}), 7.40(2 \mathrm{H}, \mathrm{d}, J=8.7 \mathrm{~Hz}), 7.61(1 \mathrm{H}, \mathrm{d}, J=7.8 \mathrm{~Hz}) .{ }^{13} \mathrm{C}-\mathrm{NMR}$ $\left(100 \mathrm{MHz}, \mathrm{CDCl}_{3}\right) \delta 28.1,28.4,31.2,38.7,48.7,48.8,80.8$, 83.0, 100.4, 109.5, 111.9, 119.8, 120.2, 120.6, 121.1, 128.3, $130.6,138.3,142.3,148.8 .{ }^{19} \mathrm{~F}-\mathrm{NMR}\left(282 \mathrm{MHz}, \mathrm{CDCl}_{3}\right) \delta$-221.4.

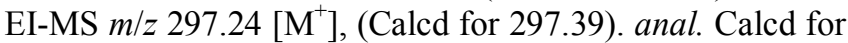
$\mathrm{C}_{19} \mathrm{H}_{21} \mathrm{~N}_{2} \mathrm{~F}$ : C, 77.000; H, 7.140; N, 9.450. Found: C, 76.605; H, 7.199; N, 9.421.

Biological evaluation. $30 \mu \mathrm{m}$ thick brain sections were obtained from frozen cortical tissue by cryostat sectioning mounted on glass microscope slides, dried at room temperature and stored at $-25{ }^{\circ} \mathrm{C}$ until experiment. The frozen sections were thawed, incubated in 4\% PBS-buffered paraformaldehyde on

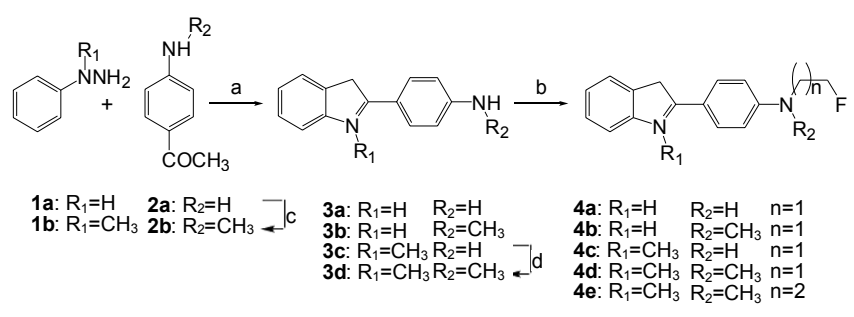

Reagents and conditions: (a) PPA, $80^{\circ} \mathrm{C}$; (b) $\mathrm{FCH}_{2} \mathrm{CH}_{2} \mathrm{Br}$ or $\mathrm{FCH}_{2} \mathrm{CH}_{2} \mathrm{CH}_{2} \mathrm{l}, \mathrm{Na}_{2} \mathrm{CO}_{3}, \mathrm{MeCN}$,

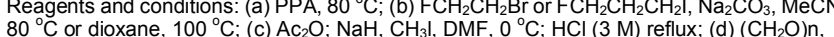

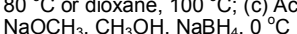

ice for $60 \mathrm{~min}$, washed twice with PBS on ice for 3 min each, incubated in xylene at room temperature for $5 \mathrm{~min}$, and eventually in $100 \%, 100 \%, 95 \%, 85 \%$ and $75 \%$ EtOH at room temperature for $1 \mathrm{~min}$ each. The PFA-fixed and xylene-incubated sections were dried at room temperature for $15 \mathrm{~min}$ and incubated with $\left[{ }^{125} \mathrm{I}\right] \mathrm{IMPY}$ alone or in the presence of $100 \mu \mathrm{M}$ IMPY to determine the nonspecific binding or $100 \mu \mathrm{M}$ of the test compounds in PBS containing $10 \% \mathrm{EtOH}$ at room temperature for $1 \mathrm{~h}$. The sections were then incubated two times in saturated $\mathrm{Li}_{2} \mathrm{CO}_{3}$ in $40 \% \mathrm{EtOH}$ and once in $40 \% \mathrm{EtOH}$ for 2 min each. The sections were dried at room temperature and exposed with ${ }^{125}$ I-sensitive imaging plates (Fuji Film, Tokyo, Japan) for $12 \mathrm{~h}$. The screen plates were analysed using image analysis system BAS-1800 II Bioimaging Analyzer (Fuji Film, Japan). Quantitative analysis of the digitized autoradiopgraphs was performed by computer assisted microdensitometry (Aida 2.31 , raytest, Germany) by measuring the photostimulated luminescence (PSL) per brain section and the area of the respective brain section $\left(\mathrm{mm}^{2}\right)$. For each brain section, the ratio PSL $/ \mathrm{mm}^{2}$ was calculated and expressed in \% of the specific binding of $\left[{ }^{125} \mathrm{I}\right] \mathrm{IMPY}$. Three independent experiments were performed.

\section{Results and Discussion}

The Fischer-Indole synthesis has been widely studied and applied for the preparation of indole derivatives. ${ }^{19}$ Polyphosphoric acid (PPA), as catalyst and solvent, plays an important role in the one-pot reaction. ${ }^{20}$ As shown in Scheme 1, 3a was synthesized from 1a and 2a in PPA at $80^{\circ} \mathrm{C}$. 2a was acetylated first by acetic anhydride in pyridine followed by methylation with $\mathrm{CH}_{3} \mathrm{I}$ and $\mathrm{NaH}$ in DMF. After removal of the acetyl group (3 $\mathrm{M} \mathrm{HCl}$ ), $N$-methylaminoacetophenone (2b) was obtained, which was used to synthesize indole $\mathbf{3 b}$ with high yield. $\mathbf{3} \mathbf{c}$ was achieved by reaction of $\mathbf{1 b}$ with $\mathbf{2 a}$ according to the same procedure as described for $\mathbf{3 a}$. The anilino group in $\mathbf{3 c}$ was monomethylated with paraformaldehyde, $\mathrm{NaOCH}_{3}$ and $\mathrm{NaBH}_{4}$ in methanol to get 3d. The 2-fluoroethyl derivatives $4 \mathbf{a}-\mathbf{d}$ were achieved by the alkylation of 3a-d with 1-bromo-2-fluoroethane in dioxane or acetonitrile in the presence of $\mathrm{Na}_{2} \mathrm{CO}_{3}$. The homologous compound $\mathbf{4 e}$ was prepared from $3 \mathrm{~d}$ and 1 -fluoro3 -iodopropane with the same method of $\mathbf{4 b}$. The ${ }^{1} \mathrm{H}-,{ }^{13} \mathrm{C}-,{ }^{19} \mathrm{~F}-$ NMR spectra, MS spectra and elemental analysis for all final compounds and intermediates were in accordance with the assigned structures.

The interaction of the newly synthesized compounds with $\left[{ }^{125} \mathrm{I}\right] \mathrm{IMPY}$-labelled brain structures was analyzed at first on human postmortem cortex obtained from one patient suffering from Alzheimer's disease. The autoradiographic images were shown on Fig. 3. To avoid the brain tissue consuming technique of homogenate assays, radiotracer displacement studies were performed on brain slices and analyzed by digital autoradiography. $\left[{ }^{125} \mathrm{I}\right] \mathrm{IMPY}$ was reported to bind with high affinity to AD cortical homogenate $\left(K_{\mathrm{D}}=5.3 \mathrm{nM}\right)^{21}$ and has been widely used as radioligand to determine the $K_{\mathrm{i}}$ values of candidate $\beta$ sheet ligands. Considering the similar chemical structure of IMPY and the newly synthesized indole derivatives, the radioligand and the test compounds are expected to interact comparably with $\beta$-sheet structures. IMPY and $\left[{ }^{125} \mathrm{I}\right] \mathrm{IMPY}$ were 


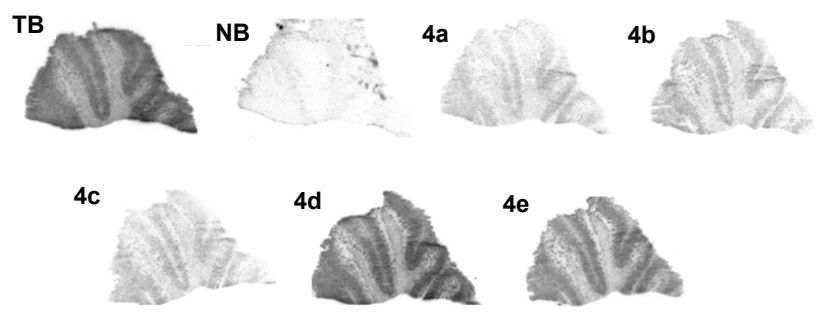

Figure 3. In vitro autoradiography on 4a-e displacement with $\left[{ }^{125} \mathrm{I}\right]$ IMPY-labelled AD human brain postmortem. TB: $\left[{ }^{125} \mathrm{I}\right] \mathrm{IMPY}$-labelled AD human brain postmortem; NB: IMPY displacement with [ ${ }^{125}$ I]IMPYlabelled $\mathrm{AD}$ human brain postmortem; $4 \mathbf{a}-\mathbf{4 e}$ : compound 4a-e displacement with ${ }^{125}$ I]IMPY-labelled AD human brain postmortem.

Table 1. Displacement by newly synthesized indole derivatives of specific binding of $\left[{ }^{125} \mathrm{I}\right] \mathrm{IMPY}$ in human $\mathrm{AD}$ brain sections assessed by digital autoradiography in vitro

\begin{tabular}{cc}
\hline Ligand at $100 \mu \mathrm{M}$ & $\begin{array}{c}\text { Specific binding of }\left[{ }^{125} \mathrm{I}\right] \mathrm{IMPY} \text { to AD } \\
\text { brain sections }\end{array}$ \\
\hline $\mathbf{4 a}$ & $10 \pm 2 \%$ \\
$\mathbf{4 b}$ & $13 \pm 3 \%$ \\
$\mathbf{4 c}$ & $14 \pm 6 \%$ \\
$\mathbf{4 d}$ & $84 \pm 15 \%$ \\
$\mathbf{4 e}$ & $47 \pm 8 \%$ \\
\hline
\end{tabular}

All data are presented as mean values $(n=3) \pm$ SD.

synthesized and labeled with ${ }^{125} \mathrm{I}$ according to the procedures described in the literature. ${ }^{21}$ Autoradiographic investigation in vitro demonstrated that at $100 \mu \mathrm{M} \mathbf{4 a}, \mathbf{4 b}, \mathbf{4 c}$ displaced a higher amount of specific $\left[{ }^{125} \mathrm{I}\right] \mathrm{IMPY}$ binding to $\mathrm{AD}$ brain tissue than $\mathbf{4 d}$ and $4 \mathbf{e}$ (86 to $90 \%$ vs. 16 to $53 \%$ displacement of specific binding, respectively; Table 1). Thus, the indole derivatives which contain only secondary amines (4a) or carry a single methyl substitution either at the indole-N (4b) or aniline-N (4c) possess an affinity to IMPY-labelled sites comparable to the thioflavin $\mathrm{T}$ itself. However, the methylation of both the aniline-N and the indole-N in $\mathbf{4 e}$ and $\mathbf{4 d}$, respectively, reduced the $\left[{ }^{125} \mathrm{I}\right] \mathrm{IMPY}$ displacement efficacy significantly. Compared to fluoroethyl substitution in $\mathbf{4 d}$, the fluoropropyl substituted $\mathbf{4 e}$ is assumed to show a somewhat higher affinity to IMPYlabelled structures in $\mathrm{AD}$ brain slices.

In summary, in this work nine indole derivatives were successfully synthesized. Five fluorine-substituted compounds were investigated regarding their affinity to human $\mathrm{AD}$ brain tissue in vitro. Indole derivatives $\mathbf{4 a}, \mathbf{4 b}$, and $\mathbf{4 c}$ displayed the potential to develop ${ }^{18} \mathrm{~F}$-labeled PET tracers for imaging neuropathological hallmarks in $\mathrm{AD}$ brain in vivo.

Acknowledgments. This work was supported by the China Scholarship Council.

\section{References}

1. Hardy, J. A.; Selkoe, D. J. Science 2002, 297, 353.

2. Hardy, J. A.; Higgins, G. A. Science 1992, 256, 184.

3. Braak, H.; Braak, E. Acta Neuropathol. 1991, 82, 239.

4. Iqbal, K.; Grundke-Iqbal, I.; Smith, A. J.; George, L.; Tung, Y. C.; Zaidi, T. Proc. Natl. Acad. Sci. USA 1989, 86, 5646.

5. Mathis, C. A.; Wang, Y.; Holt, D. P.; Huang, G. F.; Debnath, M. L.; Klunk, W. E. J. Med. Chem. 2003, 46, 2740.

6. Klunk, W. E.; Engler, H.; Nordberg, A.; Wang, Y.; Blomqvist, G.; Holt, D. P.; Bergstrom, M.; Savitcheva, I.; Huang, G. F.; Estrada, S.; Ausen, B.; Debnath, M. L.; Barletta, J.; Price, J. C.; Sandell, J.; Lopresti, B. J.; Wall, A.; Koivisto, P.; Antoni, G.; Mathis, C. A.; Langstrom, B. Ann. Neurol. 2004, 55, 306.

7. Ono, M.; Wilson, A.; Nobrega, J.; Westaway, D.; Verhoeff, P.; Zhuang, Z. P.; Kung, M. P.; Kung, H. F. Nucl. Med. Biol. 2003, 30,565 .

8. Verhoeff, N. P.; Wilson, A. A.; Takeshita, S.; Trop, L.; Hussey, D.; Singh, K.; Kung, H. F.; Kung, M. P.; Houle, S. Am. J. Geriatr. Psychiatry 2004, 12, 584.

9. Kudo, Y.; Okamura, N.; Furumoto, S.; Tashiro, M.; Furukawa, K.; Maruyama, M.; Itoh, M.; Iwata, R.; Yanai, K.; Arai, H. J. Nucl. Med. 2007, 48, 553.

10. Shoghi-Jadid, K.; Small, G. W.; Agdeppa, E. D.; Kepe, V.; Ercoli, L. M.; Siddarth, P.; Read, S.; Satyamurthy, N.; Petric, A.; Huang, S. C.; Barrio, J. R. Am. J. Geriatr. Psychiatry 2002, 10, 24.

11. Small G. W.; Kepe, V.; Ercoli, L. M.; Siddarth, P.; Bookheimer, S. Y.; Miller, K. J.; Lavretsky, H.; Burggren, A. C.; Cole, G. M.; Vinters, H. V.; Thompson, P. M.; Huang, S. C.; Satyamurthy, N.; Phelps, M. E.; Barrio, J. R. N. Engl. J. Med. 2006, 355, 2652.

12. Small, G. W.; Siddarth, P.; Burggren, A. C.; Kepe, V.; Ercoli, L. M.; Miller, K. J.; Lavretsky, H.; Thompson, P. M.; Cole, G. M.; Huang, S. C.; Phelps, M. E.; Bookheimer, S. Y.; Barrio, J. R. Arch. Gen. Psychiatry 2009, 66, 81.

13. Zhuang, Z. P.; Kung, M. P.; Wilson, A.; Lee, C. W.; Plossl, K.; Hou, C.; Holtzman, D. M.; Hung, H. F. J. Med. Chem. 2003, 46, 237.

14. Kung, M. P.; Hou, C.; Zhuang, Z. P.; Zhang, B.; Skovronsky, D.; Trojanowski, J. Q.; Lee, V. M.; Kung, H. F. Brain Res. 2002, 956, 202.

15. Newberg, A. B.; Wintering, N. A.; Plossl, K.; Hochold, J.; Stabin, M. G.; Watson, M.; Skovronsky, D.; Clark, C. M.; Kung, M. P.; Kung, H. F. J. Nucl. Med. 2006, 47, 748.

16. Klunk, W. E.; Wang, Y. M.; Huang, G. F.; Debnath, M. L.; Holt, D. P.; Mathis, C. A. Life Sci. 2001, 69, 1471.

17. Klunk, W. E.; Wang, Y. M.; Huang, G. F.; Debnath, M. L.; Holt, D. P.; Shao, L.; Hamilton, R. L.; Ikonomovic, M. D.; Dekosky, S. T.; Mathis, C. A. J. Neurosci. 2003, 23, 2086.

18. Okamura, N.; Suemoto, T.; Furumoto, S.; Suzuki, M.; Shimadzu, H.; Akatsu H.; Yamamoto, T.; Fujiwara, H.; Nemoto, M.; Maruyama, M.; Arai, H.; Yanai, K.; Sawada, T.; Kudo, Y.J. Neurosci. 2005, 25(47), 10857.

19. Humphrey, G. R.; Kuethe, J. T. Chem. Rev. 2006, 106, 2875.

20. Chikvaidze, I. S.; Mumladze, E. A.; Samsoniya, S. A.; Suvorov, N. N. Pharm. Chem. J. 1994, 28, 751.

21. Kung, M. P.; Hou, C.; Zhuang, Z. P.; Skovronsky, D.; Kung, H. F. Brain Res. 2004, 1025, 98 . 